\title{
A Researcher's View on the Proposal of Legal Regulations Regarding Major Accident Hazard Assessment in the Land-Use Planning Process in Poland
}

\begin{abstract}
This paper aims at reviewing the core Polish regulations on land-use planning (LUP) around hazardous plants and presenting a researcher's view on the proposal of a ministerial ordinance on safety distance determination from the plants creating a major accident hazard (Seveso establishments). Currently there are no legal regulations concerning the method of safety distance determination from Seveso establishments in Poland. The method of generic-distances recommended in the Polish guidelines from 2007 is not mandatory. The author stands by her opinion expressed for the first time in 2015 that Polish legal regulations on safety distance determination from Seveso establishments formulated as a ministerial ordinance are indisputably needed. If the ordinance is issued, it will contribute to a more complete implementation of the Directive 2012/18/EU and will allow nationwide unification of the method of safety distance determination. The consequence-based approach seems a reasonable option in Polish conditions. This researcher suggests an extension of the draft of the ordinance by introducing a reference tool for the mathematical modelling of accident consequences. It is also worth considering the introduction of legal norms for the description of areas designed in the spatial planning documents for the location of Seveso establishments.
\end{abstract}

Keywords: Seveso establishment, major accident, land-use planning, hazard assessment, safety distance

Received: 18 February 2020; accepted: 6 May 2020

(C) 2020 Author. This is an open access publication, which can be used, distributed and reproduced in any medium according to the Creative Commons CC-BY 4.0 License.

1 Warsaw University of Technology, Faculty of Building Services, Hydro and Environmental Engineering, Warsaw, Poland, email: maria.markiewicz@pw.edu.pl

ORCID ID: https://orcid.org/0000-0002-6180-0947 


\section{Introduction}

Land-use planning (LUP) regulations around plants that may create a major accident hazard are formulated in the Directive 2012/18/EU (the Seveso III Directive) [1] in Article 13. The philosophy behind LUP is to maintain appropriate distance (the safety distance) between the establishments covered by the Seveso III Directive (Seveso establishments) and sensitive areas (such as residential areas, areas of substantial public use and other areas of particular interest or sensitivity) in case of a major accident. It is required that EU Member States introduce LUP criteria to their legislation. EU countries either have already developed compliance with these requirements or are still searching for their own ways to achieve it.

Generally, there are three main approaches to taking into account a major accident hazard in LUP: a generic-distances approach, a consequence-based approach and a risk-based approach. The generic-distances are proposed for categories of industry or for types and quantities of dangerous substances present in the plant. The consequence-based approach focuses on the assessment of consequences of a number of reference accident scenarios without attempting to quantify a likelihood of these scenarios. The risk-based approach defines the risk as a combination of the consequences derived from a range of possible accidents, and the likelihood of these accidents. Two measures of risk are usually calculated: individual risk and societal risk. The first parameter is defined as "the probability of fatality due to an accident in the installation for an individual being at a specific point". The second parameter is defined for different groups of people and it is "the probability of occurrence of any accident resulting at fatalities greater or equal to a specific figure" $[2,3]$.

The aim of the paper is twofold:

- to review the core Polish regulations on LUP around hazardous establishments and,

- to present this researcher's view on the method of safety distance determination from plants which constitute a major accident hazard as formulated in the proposal of a ministerial ordinance dated 26 March 2019 [4].

Currently there are no legal regulations concerning the method of safety distance determination from plants constituting a major accident hazard in Poland. The method of generic-distances recommended in the Polish guidelines from 2007 [5, 6] is not mandatory and has not been effectively used in the spatial planning routine in Poland. The paper describes the legal status as per 20 March 2020.

The methodology used is a combination of both the analysis of Polish regulations and a literature study. The basic research question to be answered is: "Are the legal regulations concerning safety distance determination needed in Poland and, if so, is the method of safety distance determination included in the proposal of a new ministerial ordinance fit to tackle the problem?". 
The literature review has shown that only three papers are published in the scientific journals regarding the issue of LUP around Seveso establishments in Poland. All three papers are case studies. Two papers by this author present the results of the analysis of the spatial planning documents prepared at the municipality level with regard to a major accident hazard [7, 8]. The third paper, written by Wiśniewski, Połeć and Sobieszek [9], focuses on the results of the evaluation of the quality of the safety reports prepared by the operators of the upper tier establishments (UTEs). Although all these articles refer to the issue of safety distance determination, none of them provides a detailed discussion on the method of safety distance determination proposed in the draft of a ministerial ordinance dated 26 March 2019 [4]. The author believes that the paper fills a gap in the scientific literature, can be of interest for readers from different disciplines and will stimulate further discussion in a broader scientific forum on this important issue.

\section{Legal Acts Regarding LUP around the Seveso Establishments in Poland}

The Seveso III Directive [1] has been transposed into Polish law by the Act of 23 July 2015 amending the Environmental protection law and other acts [10]. Legal acts regarding LUP around the Seveso establishments in Poland are listed in Table 1. A set of ministerial ordinances regarding this issue which have been issued on the basis of these acts is cited in the following sections.

Table 1. Polish legal acts regarding LUP around the Seveso establishments in Poland

\begin{tabular}{|l|l||}
\hline \multicolumn{1}{|c|}{ Name of the Polish legal act } & \multicolumn{1}{|c|}{ Notation in the Polish Journal of Laws } \\
\hline $\begin{array}{l}\text { Act of 27 April 2001 - Environmental protection } \\
\text { law (the EPL Act) }\end{array}$ & $\begin{array}{l}\text { Journal of Laws of 2001, no. 62, item 627 with later } \\
\text { amendments [11] }\end{array}$ \\
\hline $\begin{array}{l}\text { Act of 24 August 1991 on the State Fire Service } \\
\text { (the SFS Act) }\end{array}$ & $\begin{array}{l}\text { Journal of Laws of 1991, no. 88, item } 400 \text { with later } \\
\text { amendments [12] }\end{array}$ \\
\hline $\begin{array}{l}\text { Act of 20 July 1991 on the Inspection } \\
\text { for Environmental Protection (the IEP Act) }\end{array}$ & $\begin{array}{l}\text { Journal of Laws of 1991, no. 77, item } 335 \text { with later } \\
\text { amendments [13] }\end{array}$ \\
\hline $\begin{array}{l}\text { Act of 3 October 2008 on making available } \\
\text { information about environment its protection, } \\
\text { the public's participation in environmental } \\
\text { protection, as well as on environmental impact } \\
\text { assessment (the MAIEP Act) }\end{array}$ & $\begin{array}{l}\text { Journal of Laws of 2008, no. 199, item 1227 } \\
\text { with later amendments [14] }\end{array}$ \\
\hline $\begin{array}{l}\text { Act of 27 March 2003 on spatial planning } \\
\text { and land-use management (the SPLUM Act) }\end{array}$ & $\begin{array}{l}\text { Journal of Laws of 2003, no. 80, item 717 with later } \\
\text { amendments [15] }\end{array}$ \\
\hline
\end{tabular}




\section{System for the Prevention of Major Accidents in Poland}

The overall coordination and control functions for the prevention of major accidents in Poland are assigned to the State Fire Service (SFS) with the participation of the Inspection of Environment Protection (IEP) (Tab. 2).

Table 2. Polish legal acts regarding LUP around the Seveso establishments in Poland

\begin{tabular}{|c|c|}
\hline Tasks of the SFS & Tasks of the IEP \\
\hline $\begin{array}{l}\text { Expressing opinions and approvals of documents } \\
\text { prepared by operators of the Seveso } \\
\text { establishments. Developing external emergency } \\
\text { plans for the UTEs }{ }^{1)} \text { based on the information } \\
\text { supplied by operators. The method of supplying } \\
\text { information is regulated by the ordinance (Journal } \\
\text { of Laws of 2002, no. 175, item 1439) [16] }\end{array}$ & $\begin{array}{l}\text { Carrying out research on causes of major accidents } \\
\text { and the ways of elimination of the effects of major } \\
\text { accidents on the environment }\end{array}$ \\
\hline $\begin{array}{l}\text { Determining a group of plants whose location } \\
\text { next to each other can cause domino effects }\end{array}$ & $\begin{array}{l}\text { Keeping a register of establishments whose } \\
\text { activity may cause a major accident }\end{array}$ \\
\hline $\begin{array}{l}\text { Sharing information about a major accident } \\
\text { hazard in the Public information bulletin. } \\
\text { Ensuring public information process. The range } \\
\text { of information is determined in Art. 267(1) } \\
\text { of the EPL Act and the ordinance (Journal of Laws } \\
\text { of } 2002 \text { no. 78, item 712) [17] }\end{array}$ & $\begin{array}{l}\text { Keeping a register of major accidents, which } \\
\text { should be reported to the Chief Inspector } \\
\text { of the IEP. Conditions, which decide to classify an } \\
\text { event as a major accident regulate the ordinances } \\
\text { (Journal of Laws of 2003, no. 5, item 58) [18] and } \\
\text { (Journal of Laws of 2016, item 799) [19] }\end{array}$ \\
\hline $\begin{array}{l}\text { Carrying out inspections of plants, whose activity } \\
\text { may constitute the cause of a major accident, } \\
\text { including the Seveso establishments. The way } \\
\text { of conducting control is regulated by Art. } 269 \mathrm{a}(1) \\
\text { of the EPL Act and the ordinance (Journal of Laws } \\
\text { of } 2005 \text {, no. 225, item 1934) [20] }\end{array}$ & $\begin{array}{l}\text { Carrying out inspections (usually in cooperation } \\
\text { with the SFS) }\end{array}$ \\
\hline
\end{tabular}

1) Plants covered by the Seveso III Directive are divided into two groups: the lower tier establishments (the LTEs) and the upper tier establishments (the UTEs). According to the Chief of the IEP at the end of 2018 there were 184 of the LTEs and 255 of the UTEs in Poland.

Source: own elaboration based on the EPL Act [11], the SFS Act [12] and the IEP Act [13]

Qualification criteria of the Seveso establishments (i.e. the lower tier establishments (the LTEs) and the upper tier establishments (the UTEs) respectively) are discussed in detail in the ordinance (Journal of Laws of 2016, item 138) [21]. Operators of Seveso establishments are obliged to take all necessary measures to prevent major accidents and to limit their consequences for human health and the environment. Operators of the LTEs or the UTEs are obliged to notify the competent authorities (the County/City Commander of the SFS in matters involving the LTE and the Provincial Commander of the SFS in matters concerning the UTE; and the Provincial 
Inspector of the IEP) of the establishments. They are obliged to draw-up a number of documents regarding the safety and effective prevention of industrial accidents and submit them to the competent authority of the SFS as well as send them to the Provincial Inspector of the IEP (Fig. 1). The EPL Act [11] regulates what the required documents should contain (Art. 251(3, 4), Art. 252(2, 3, 4), Art. 253(2), Art. 260(2)). In addition, detailed requirements for the contents of the safety report and the emergency plans are specified respectively in the ordinances (Journal of Laws of 2016, item 287) [22] and (Journal of Laws of 2016, item 821) [23].

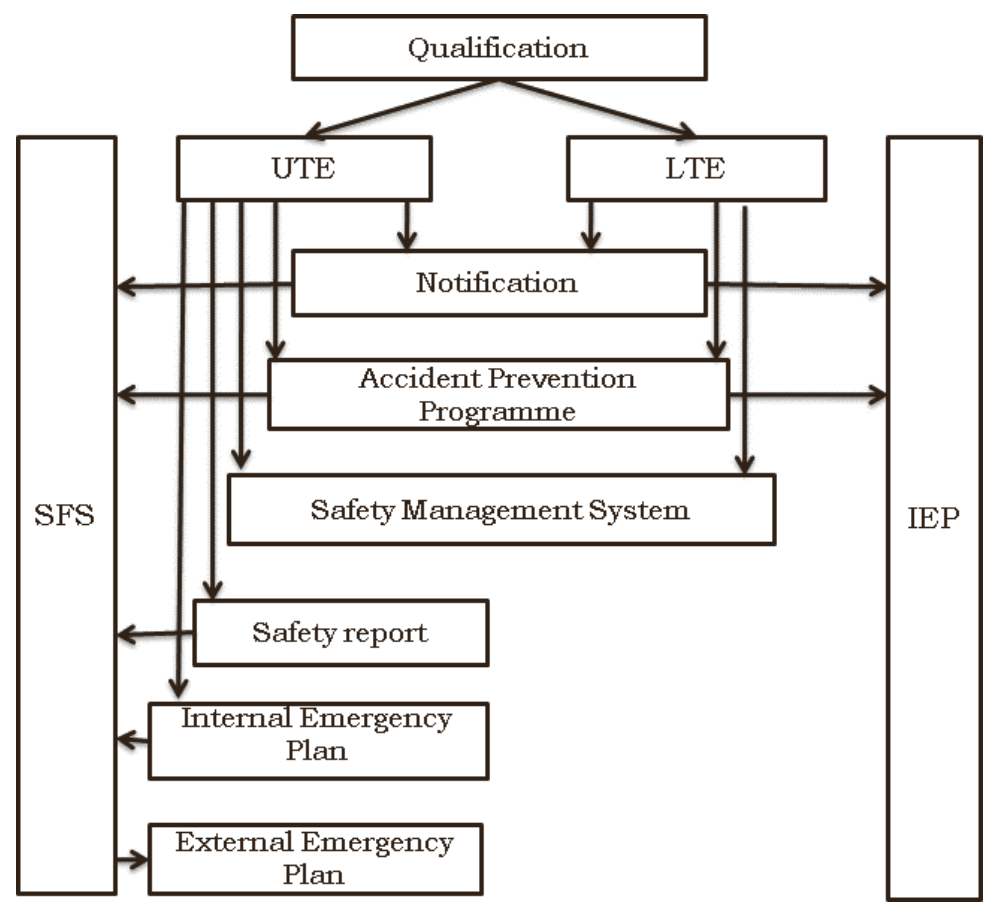

Fig. 1. Documents regarding the safety and effective prevention of accidents prepared by operators of Seveso establishments in Poland

Source: own elaboration based on the EPL Act [11]

It is important to notice that, according to the ordinance (Journal of Laws of 2016, item 287) [22], the safety report, among other information, has to provide information for LUP purposes. It should be emphasised that there are no legal regulations that specify how to identify a major accident hazard and assess the risk of a major accident in the process of preparing safety reports in Poland. Polish regulations, in particular the MAIEP Act [14], provide public participation in decision making related to the hazardous establishments and nearby developments as well as on plans and programmes. 


\section{System of Spatial Planning in Poland}

Spatial planning takes place in Poland at the national, regional, sub-regional and municipality levels. However, the preparation of spatial planning documents is only obligatory at the national, regional and municipality levels. Polish regulations allocate a decisive role in spatial planning to municipalities. At this level, decisions are made concerning the location of specific functions, the intensity of land-use, scales and forms of constructions. The body responsible for supervising the drafting of two spatial planning documents at this level (the study of the conditions and directions for the spatial development of the municipality (the study) and a land use development plan (the plan)) is the head of the rural municipality, mayor, or city president. The study determines the spatial policy in a municipality. It is an obligatory document but not legally binding and is prepared for the whole municipality area. The layout and content of the study regulate Art. 10(1) of the SPLUM Act [15] and the ordinance (Journal of Laws of 2004, no. 119, item 1233) [24]. The plan constitutes an essential tool for implementing the municipality spatial policy formulated in the study. The local council adopts the plan in the form of a local by-law. As a rule, other tasks proposed by a higher tier of government can only be introduced into the plan through negotiations. It might be prepared for the whole municipality area or only its part. It is important to notice that there is no obligation to draw-up the plan if the Seveso establishments are present in the area already or if siting these investments is planned. The layout and content of the plan regulate Art. (15(1) and (3)) of the SPLUM Act [19] and the ordinance (Journal of Laws of, no. 164, item 1587) [25].

In the absence of the plan, the municipality authorities can manage spatial development through ordering the decision on development conditions or the decision on location of a public purpose investment (the decisions). This second decision is issued in case of a public purpose investment. It is worth mentioning that there are no legal regulations that require these decisions to be compliant with the provisions of the study [26-28]. These decisions are issued on the basis of Art. 59 and Art. 50 of the Act on SPLUM [15] respectively and the ordinances (Journal of Laws of 2003, no. 164, item 1588) [29] and (Journal of Laws of 2003, item 1589) [30]. The decision on development conditions may be only issued if the conditions specified under Art. 61 of the Act on SPLUM [15] are jointly met. The body authorized to issue these decisions is the head of the rural municipality, mayor, or city president, except for decisions pertaining to closed areas, which may be issued by the voivode. During the decision's term of validity, it is binding upon the competent authorities responsible for issuing the building permit. The decision on a building permit may be granted exclusively based on the plan, the decision on development conditions or the decision on location of a public purpose investment. It is issued - as a matter of principle - by the head of the county, who acts as of the first instance of the architectural and construction body. 
As far as the spatial planning documents are concerned, in the regulations specifying their content there in no explicit reference to the issue of a major accident hazard. But this issue falls within the scope of the broader issue of health protection, safety of people and their property which, according to the SPLUM Act [15], has to be taken into account in all activities related to spatial planning, in particular in drawing-up drafts of the study and the plan. The authorities of the SFS and the Provincial Inspector of the IEP are recognised as the competent authorities to cooperate in drawing-up the said documents and decisions. This cooperation includes expressing agreements (the study, the decisions) and opinions (the plan), requesting and sharing information. The links between the spatial planning documents prepared at the municipality level and the documents accompanying them are presented in Figure 2. The ecophysiographic document has to be prepared before starting the work on drawing-up a draft of the study and a draft of the plan. The scope of this document is specified in the ordinance (Journal of Laws of 2002, no. 155, item 1298) [31]. The ordinance does not directly refer to the issue of a major accident hazard. However, it can be considered that this issue falls within the scope of the issue of environmental hazard, which has to be recognized and characterized in this document.

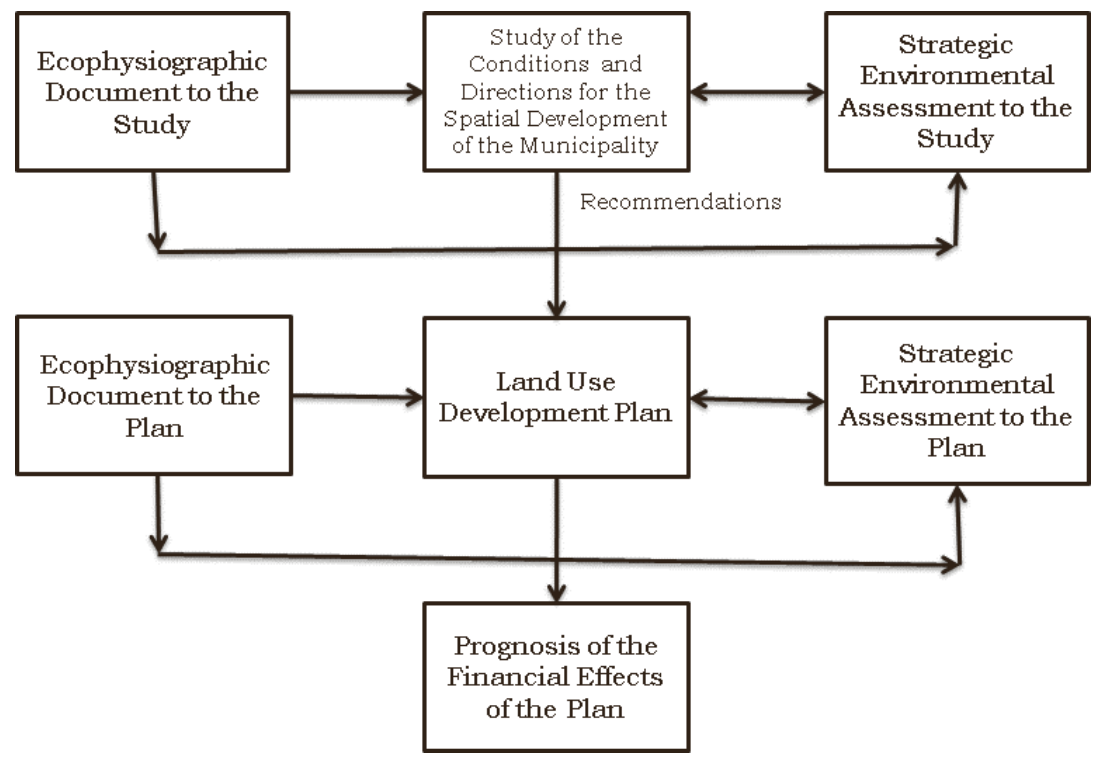

Fig. 2. A relation between the spatial planning documents prepared at the municipality level and the documents accompanying them

It is obligatory to prepare the strategic environmental assessment (SEA) report for a draft of the study and a draft of the plan. As in the case of the ecophysiographic document, the major accident issue is not explicitly listed in the scope of the SEA document. The need to consider it in the SEA document results from 
Art. 51(2) of the MAIEP Act [14]. According to this article the SEA document defines, evaluates and predicts significant impacts of the provisions of the spatial planning document on the elements of the natural environment as well as provides solutions aimed at preventing, reducing and compensating for negative effects on the natural environment.

The environmental impact assessment (EIA) must always be conducted for the purpose of the decision on environmental conditions for a planned investment that is likely to have a significant impact on the environment. It is also required for a planned investment that may have a high impact on the environment if the authority issuing the decision on environmental conditions determines this by means of a decision. Affiliation of an investment to a group of the Seveso plants itself does not determine the need for the EIA.

\section{Polish Legal Regulations on Maintaining Safety Distances from Hazardous Plants}

The most important Polish regulations referring to the issue of taking into account a major accident hazard in LUP is Art. 73 of the EPL Act [11] (Tab. 3).

Table 3. Article 73 of the EPL Act [11]

\begin{tabular}{|c|l|}
\hline $\begin{array}{c}\text { Art. } \\
73(\S)\end{array}$ & \multicolumn{1}{c|}{ Content } \\
\hline \hline 1 & $\begin{array}{l}\text { In the land-use development plan and the decision on development conditions shall be } \\
\text { included in particular the restrictions resulting from: 1) establishing, pursuant to the Act of } \\
\text { 16 April 2004 on protection of nature [32] of a national park, nature reserve, landscape park, } \\
\text { protected landscape area, area of Natura 2000, natural and landscape complex, ecological } \\
\text { ground, documentation site, natural monuments and their buffer zones; 2) creating limited } \\
\text { use areas or industrial zones; 2a) the designation of quiet areas in the agglomeration and } \\
\text { quiet areas outside the agglomeration; 2b) strategic noise maps; 3) establishing, pursuant } \\
\text { to the provisions of the Act of 20 July 2017 - Water law [33] of the conditions of utilisation } \\
\text { of waters from water regions and the catchment area, and establishing protection zones for } \\
\text { water intakes, as well as protection areas for inland water reservoirs }\end{array}$ \\
\hline 2 & $\begin{array}{l}\text { Communication lines, overhead and underground pipelines, cable lines and other line } \\
\text { facilities are carried out and constructed in the way that reduces their environmental impact, } \\
\text { including 1) protection of landscape values; 2) the possibility of movement of wild animals }\end{array}$ \\
\hline 3 & $\begin{array}{l}\text { The location of plants, which are dangerous to human life or health, in particular may create } \\
\text { a major accident hazard, is forbidden within the administrative municipality boundary and } \\
\text { within close village premises. The extension of these plants is acceptable under the condition } \\
\text { of causing reduction of danger to human health, in particular the reduction of creating } \\
\text { a major accident hazard }\end{array}$ \\
\hline $3 a$ & $\begin{array}{l}\text { The regulation in § 3 does not apply to the construction and extension of establishments } \\
\text { in the areas referred to in the land-use development plans as the areas intended for } \\
\text { production facilities, warehouses and storage facilities, if these plans do not contain } \\
\text { restrictions on establishments posing a hazard to human life and health }\end{array}$ \\
\hline
\end{tabular}


Table 3 cont.

\begin{tabular}{|c|l||}
\hline 4 & $\begin{array}{l}\text { The location of establishments creating a major accident hazard should take into account } \\
\text { the safety distance from other establishments creating a major accident hazard, from } \\
\text { multi-family residential buildings, from residential buildings constructed on real estate } \\
\text { from the Real Estate Stock referred to in the Act of 20 July 2017 on the National Real Estate } \\
\text { Stock [34], from public utility facilities, from buildings of collective residence, from areas } \\
\text { protected by the provisions of the Act of 14 April 2004 on the protection of nature [32] } \\
\text { and the Act of 20 July 2017 - Water law [33], from national roads and from railway lines } \\
\text { of national importance }\end{array}$ \\
\hline 5 & $\begin{array}{l}\text { The location of multi-family residential buildings, residential buildings constructed on real } \\
\text { estate from the Real Estate Stock referred to in the Act of 20 July 2017 on the National Real } \\
\text { Estate Stock [34], public utility facilities, buildings of collective residence, areas protected } \\
\text { by the provisions of the Act of 14 April 2004 on the protection of nature [30] and the Act } \\
\text { of 18 July 2001 - Water law [33], national roads and railway lines of national importance } \\
\text { should take into account the safety distance from existing establishments creating a major } \\
\text { accident hazard }\end{array}$ \\
\hline 6 & $\begin{array}{l}\text { For existing establishments, which were located without keeping the safety distance, } \\
\text { the relevant authorities of the Inspectorate of EP (the Provincial Inspectors of EP) } \\
\text { after obtaining the opinion of the competent authority of the SFS (the Provincial } \\
\text { Commander of the SFS in case of the UTEs and the County/City Commander of the SFS } \\
\text { in case of the LTEs), in order to increase people's safety, may require implementing } \\
\text { additional technical measures }\end{array}$ \\
\hline 7 & $\begin{array}{l}\text { The County/City Commander of the SFS may, after consulting the County Inspector of EP, } \\
\text { issue a decision imposing on the operator of the LTE an obligation to prepare and submit } \\
\text { information on: 1) the likelihood of a major industrial accident; 2) potential consequences } \\
\text { of a major industrial accident and their range for land-use planning purposes }\end{array}$ \\
\hline 8 & $\begin{array}{l}\text { The costs of preparing and submitting information referred to in § 7 are covered by } \\
\text { the operator of the LTE }\end{array}$ \\
\hline
\end{tabular}

Source: Article 73 of the EPL Act [11]

\section{Principles of the Hazard Assessment Method Recommended in the Polish Guidelines}

The core of the hazard assessment method described in the Polish guidelines from 2007 entitled "Methodology for determining safety locations of plants that may cause major accidents" is the generic-distance approach [5, 6]. In the framework of drawing-up the study, it is recommended to use tabular values of generic-distances that depend on the category and type of industry. In the framework of preparing the plan it is proposed to use tabular values of generic distances that depend on the category and type of industry, the types of dangerous substances and their amounts at the premises of the Seveso establishment. The same applies to the decision on development conditions, the decision on location of a public purpose investment and the decision on building permit. In case of areas designed for industry in which Seveso establishments can be located, an extended description has been proposed, clearly informing about such use of this area. When there is no data in the ranking 
tables for the given establishment or the more detailed analysis is needed it is recommended to carry out the analysis on a case-by-case basis. However, no further information is provided about this analysis. It is important to notice that it has not been mandatory under the Polish guidelines [5].

\section{Principles of the Hazard Assessment Method Described in the Proposal of the Ministerial Ordinance}

The statutory authorization to issue the ordinance of the Polish Ministry of Environment on safety distance determination from plants constituting a major accident hazard is included in Article 73a of the EPL Act [11]. It was introduced in 2015 by the Act of 23 July 2015 amending the Environmental protection law and some other acts [10]. The work on the draft of this ordinance has been carried out since 2015. The third version of the proposal dated 26 March 2019 is available on the website of the Governmental Legislative Centre [4]. The proposal describes the method of safety distance determination in the case of location of a new plant that may cause major accident, and in case of the location of new developments (facilities) in the area in which a Seveso plant is already present. The core of the proposed method of safety distance determination is the consequence-based approach. This requires identification of major accident scenarios from a pre-described list with consideration of the spatial distribution of physical effects of these accidents. The pre-described list of scenarios includes nine types of major accidents (jet fire, pool fire, fireball, fire of vapours or gases, boiling and escape of flammable liquids from the tank, explosion of vapours or gases, high energy material explosion or explosive decomposition of peroxides, emission of toxic vapours or gases, emission of flammable vapours or gases). The main parameters of major accidents are specified for events involving four groups of substances (flammable liquids and flammable liquefied gases, flammable gases, liquids and toxic gases, explosives and peroxides). In the calculations it is proposed to take into account only major accidents, the likelihood of occurrence of which is not less than $10^{-6}$ per year and whose consequences extend beyond the plant premises. It is proposed to perform simulations for one set of meteorological conditions (wind velocity $15 \mathrm{~m} / \mathrm{s}$, atmospheric stability D and atmospheric temperature $20^{\circ} \mathrm{C}$ ) and a terrain roughness coefficient characteristic for the plant location using a specific set of endpoints. These endpoints are defined by five intensity levels of thermal radiation (flammable substances), overpressure (explosive substances) or toxic concentration (toxic substances) that cause specific effects on people or properties. Each level of intensity of undesired effects (Tab. 4) is assigned to specific types of facilities or types of land-use depending on their vulnerability (Tab. 5). The effect zones are then defined based on the distances to the endpoints corresponding to the worst of the reference scenarios as concentric rings around the plant. Compatibility between the level of vulnerability of facilities and 
types of land-use and the hazard related to their location within the effects zones is assessed based on the proposed matrix of land-use policy decisions (Tab. 6).

The draft of the ordinance indicates numerous sources of information for determining the safety distance. It is proposed that these regulations enter into force one year after their publication.

Table 4. Threshold values proposed for the evaluation of consequences of major accidents in terms of flammability, explosiveness and toxicity of hazardous substances

\begin{tabular}{|c|c|c|c|c|}
\hline Damage zone & $\begin{array}{c}\text { Thermal } \\
\text { radiation } \\
(q)\end{array}$ & $\begin{array}{l}\text { Heat dose } \\
\text { (D) }\end{array}$ & $\begin{array}{l}\text { Over preassure }{ }^{1)} \\
\qquad(\Delta P)\end{array}$ & $\begin{array}{l}\text { Toxic concentration } \\
\text { (C) }\end{array}$ \\
\hline & $\mathrm{kW} / \mathrm{m}^{2}$ & $\left(\mathrm{~kW} / \mathrm{m}^{2}\right)^{4 / 3} \mathrm{~s}$ & $\mathrm{kPa}$ & - \\
\hline A & $q>37.5$ & $D>2,800$ & $\Delta P>15$ & $C>\mathrm{LC} 50^{2)}$ \\
\hline B & $37.5 \geq q>12.5$ & $2,800 \geq D>450$ & $15 \geq \Delta P>8$ & $\mathrm{LC} 50 \geq \mathrm{C}>\mathrm{PAC}-3^{3)}$ \\
\hline $\mathrm{C}$ & $12.5 \geq q>7$ & $450 \geq D>250$ & $8 \geq \Delta P>5$ & PAC $-3 \geq C>$ PAC -2 \\
\hline $\mathrm{D}$ & $7 \geq q>4$ & $250 \geq D>150$ & $5 \geq \Delta P \geq 3.5$ & PAC $-2 \geq C>$ PAC -1 \\
\hline $\mathrm{E}$ & $4 \geq q$ & $150 \geq D$ & $\Delta P \geq 3.5$ & PAC- $1 \geq C$ \\
\hline $\begin{array}{c}\text { Occurrence } \\
\text { of domino } \\
\text { effects }\end{array}$ & $q \geq 37.5$ & $D \geq 2,800$ & $\Delta P \geq 15$ & - \\
\hline
\end{tabular}

1) Applies to BLEVE (Boiling Liquid Expanding Vapour Explosion) explosions.

2) LC50 the lethal concentration should be taken for the time of exposure equal one hour.

3) If the values of PAC (Protective Action Criteria) are not available the values of AEGL (Acute Exposure Guideline Levels), ERPG (Emergency Response Planning Guidelines) and TEEL (Temporary Emergency Exposure Limit) for the time of exposure equal one hour can be applied.

Source: The draft of the ordinance of the Ministry of Environment of 26 March 2019 on safety distance determination from the plants creating a major accident hazard [4]

Table 5. Proposed classification of the level of vulnerability for different facilities and types of land-use

\begin{tabular}{|c|l|}
\hline $\begin{array}{c}\text { Vulnerability } \\
\text { level }\end{array}$ & \multicolumn{1}{c|}{ Types of facilities and land-use } \\
\hline \hline I & $\begin{array}{l}\text { Municipality roads. Agricultural areas where no buildings intended for stay } \\
\text { of humans and facilities for breeding animal are present. Waste land, where no } \\
\text { buildings intended for people and facilities for breeding animals are present }\end{array}$ \\
\hline II & $\begin{array}{l}\text { Railways (including those of national significance) }{ }^{11} \text {. Production and storage facilities. } \\
\text { Other types of public roads (including national roads) } \\
\text { hazards }\end{array}$ \\
\hline
\end{tabular}


Table 5 cont.

\begin{tabular}{|c|c|}
\hline $\begin{array}{c}\text { Vulnerability } \\
\text { level }\end{array}$ & Types of facilities and land-use \\
\hline III & $\begin{array}{l}\text { Low residential buildings. Buildings of public usage (included in category } \mathrm{ZL}^{2)} \mathrm{III}^{1)} \\
\text { up to } 500 \mathrm{~m}^{2} \text {. Areas referred to in Art. } 73(1,3) \text { of the Act of } 27 \text { April of } 2001- \\
\text { Environmental protection law. Facilities or land- use related to activities that can } \\
\text { attract no more than } 50 \text { people at one time }\end{array}$ \\
\hline IV & Types of facilities and areas not indicated in groups I, II, III, V \\
\hline V & $\begin{array}{l}\text { Facilities included in a category } \mathrm{ZL}^{2)} \mathrm{II}^{1)} \text {. Facilities included in category } \mathrm{ZL}^{2)} \mathrm{I}^{1)} \text { with } \\
\text { rooms that can accommodate more than } 500 \text { people at one time. Facilities or land-use } \\
\text { related to activities that can simultaneously attract more than } 500 \text { people at one time. } \\
\text { Collective housing facilities }\left(\mathrm{ZL}^{2)} \mathrm{V}^{1)}\right) \text { with more than } 200 \text { beds }\end{array}$ \\
\hline
\end{tabular}

1) Does not apply to railway lines and public roads where the transport is carried out for the needs of a given plant.

2) The categories of danger to people are in accordance with the fire zones specified in $\S 209(2)$ of the ordinance of the Ministry of Infrastructure of 12 April of 2002 on technical conditions to be met by buildings and their location (Journal of Laws of 2015, item 1422 and Journal of Laws of 2017, item 2285) [35, 36].

Source: The draft of the ordinance of the Ministry of Environment of 26 March 2019 on safety distance determination from the plants creating a major accident hazard [4]

Table 6. Proposed table of land-use policy decisions

\begin{tabular}{|c|c|c|c|c|c|}
\hline $\begin{array}{c}\text { Vulnerability of facilities } \\
\text { and types of land-use }\end{array}$ & Zone A & Zone B & Zone C & Zone D & Zone E \\
\hline \hline I & P & P & P & P & P \\
\hline II & NP & P & P & P & P \\
\hline III & NP & NP & P & P & P \\
\hline IV & NP & NP & NP & P & P \\
\hline V & NP & NP & NP & NP & P \\
\hline
\end{tabular}

$\mathrm{P}$ - permissible, NP - not permissible.

Source: The draft of the ordinance of the Ministry of Environment of 26 March 2019 on safety distance determination from the plants creating a major accident hazard [4]

\section{Discussion and Conclusions}

The author stands by her opinion expressed for the first time in 2015 [7], namely that the legal regulations on safety distance determination from Seveso establishments formulated as a ministerial ordinance are indisputably needed. The Polish guidelines entitled "Methodology for determining safety locations for plants that 
may cause major accidents" issued in $2007[5,6]$ have proved insufficient. The main reason that the Polish guidelines were not used in the spatial planning practise was mainly the lack of the legal validity of the guidelines $[5,6]$. It is important to note that in 2015 this view was based on the results of a case study limited to the city of Poznań [7]. Currently, this opinion is supported by a larger experimental material covering five other densely populated Polish cities: Warsaw, Kraków, Gdańsk, Wrocław and Łódź [8].

It is worth adding that the need to develop Polish legislation concerning the method of safety distance determination in 2018 was also recognised by Wiśniewski, Sobieszek and Połeć [9]. These authors performed the analysis of safety reports prepared for UTEs in the Mazowieckie Voivodeship and raised this postulate among others related to the process of preparing the safety report.

The author considers the consequence-based approach proposed in the draft of the ministerial ordinance to be a reasonable option in Polish conditions. It has the following advantages:

- it allows for the more detailed analysis then the generic-distance approach,

- it is still not as complex as the risk-based approach (there is no need for strong mathematical background for the comprehension of the method, the required data and calculation time are reasonable),

- the outputs are communicable to the general public.

It seems worth noticing that the decision on the method of defining the safety distances between Seveso establishments and sensitive areas has been left to each of the EU Member States. The heterogeneity of approaches adopted in the different countries of EU reflects the specific historical, geographical, economical, social and regulatory background of each country [2-3]. Currently the consequence-based approach has been adopted in Finland, Luxembourg, Spain and Austria [2, 3, 37, 38] and proposed in Greece [38]. As far as the generic-distances approach, this has been established in Germany and Sweden [2, 3, 37, 38], while the risk-based approach has been adopted in the UK [2, 3, 37-42] and the Netherlands [2, 3, 37, 38, 43] and proposed in Belgium [44-46]. In France [47-49] and Italy [50], after the accident in Toulouse [51], the consequence-approach has been replaced by hybrid approaches combining the advantages of the risk and consequence-based approaches. Comprehensive reviews and comparisons of different approaches are described in detail in [52-58].

This author suggests an extension of the draft of the ordinance of the Ministry of Environment of 26 March 2019 on determining the safety distance [4] by means of a reference tool for the mathematical modelling of the consequences of major accidents. There are many computer programs available for the simulation of the consequences of major accidents $[59,60]$. It is important that the quality of the recommended mathematical modelling tool is evaluated. The procedure of scientific model evaluation covers the scientific model assessment, statistical evaluation (validation), 
code assessment (assurance or verification) and user oriented assessment. In the scientific evaluation, the model algorithms, physics and assumptions are analysed in detail. The statistical evaluation consists of comparing the model results and measurements data obtained from the field and laboratory experiments. The code assessment is a check of the correctness of the code. The user-oriented assessment includes issues such as the user's guide, user interface, error control, model calculation diagnostics, processing and displaying model results [61]. Only the mathematical modelling tools evaluated with positive results should be taken into account. It seems important to recall in this context the EU Commission computer tool known as the Accident Damage Assessment Module (ADAM module) for the assessment of the consequences of an industrial accidents resulting from the accidental release of a dangerous substance. It was developed to support the competent authorities of EU Member States and other institutions involved in chemical accident prevention and preparedness. The results of the verification of this computer tool using the extensive measurement data from laboratory and field experiments are described in [62].

It is also worth considering the introduction of legal norms for the description of areas designed in the spatial planning documents for the location of Seveso establishments. This would require the introduction of changes to the ordinance regarding the content of the plan (Journal of Laws of 2003, no. 164, item 1587) [25]. According to the Polish guidelines [5] such areas could be denoted "PS" where P stands for "Industry" (in Polish "Przemyst") and S stands for "Seveso".

In conclusion, according to this author, efforts should be enhanced to complete the legislation process regarding the draft of the ministerial ordinance on safety distance determination from plants that may create a major accident hazard. If the ordinance is issued, it will contribute to a more complete implementation of the Directive 2012/18/EU and will allow for the nationwide unification of the method of safety distance determination.

\section{References}

[1] Directive 2012/18/EU of the European Parliament and of the Council of 4 July 2012 on the control of major-accident hazards involving dangerous substances, amending and subsequently repealing Council Directive 96/82/EC. Official Journal of European Union No. L197/1, 24 July 2012.

[2] Christou M., Amendola A., Smeder M.: The control of major accident hazards: The land-use planning issue. Journal of Hazardous Material, vol. 65, 1999, pp. 157-178.

[3] Christou M.D., Mattarelli M.: Land-use planning in the vicinity of chemical sites: Risk-informed decision making at a local community level. Journal of Hazardous Materials, vol. 78, 2000, pp. 191-222. 
[4] Projekt z dnia 26 marca 2019 r. Rozporzadzenia Ministra Środowiska w sprawie ustalania bezpiecznej odległości od zakładów stwarzajacych zagrożenie wystapienia poważnej awarii przemystowej [Draft of 26 march 2019 of the ordinance of the Ministry of Environment on the determination of the safety distance from the plants creating major accident hazards]. https://legislacja.rcl.gov.pl/projekt/12306856/ katalog/12483014 [access: 8.02.2020].

[5] Małaczyński M., Bańkowska B., Wieszczeczyński T.: Metodologia określania bezpiecznych lokalizacji zakładów mogących powodować poważne awarie. GIOŚ, Warszawa 2007.

[6] Małaczyński M., Bańkowska B., Wieszczeczyński T.: Metodologia określania bezpiecznych lokalizacji zakładów mogących powodować poważne awarie. Aktualizacja. GIOŚ, Warszawa 2010.

[7] Markiewicz M.T.: Analiza wybranych dokumentów planistycznych pod względem zagrożenia awariami przemysłowymi na przykładzie miasta Poznania. Bezpieczeństwo i Technika Pożarnicza, t. 40, nr 4, 2015, pp. 15-27.

[8] Markiewicz M.T.: Analysis of spatial planning documents and strategic environmental assessment reports with regard to hazards of major industrial accident: a case study involving six Polish cities. Environmental Science and Pollution Research, vol. 27, no. 3, 2020, pp. 18269-18286.

[9] Wiśniewski W., Sobieszek G., Połeć B.: Prevention of major industrial accidents - Case study using the example of the Mazowieckie Voivodeship. Bezpieczeństwo i Technika Pożarnicza, t. 51, nr 3, 2018, pp. 50-69.

[10] Ustawa z dnia 23 lipca 2015 r. o zmianie ustawy Prawo ochrony środowiska oraz niektórych innych ustaw. Dz.U. 2015 poz. 1434 [Act of 23 July 2015 amending the Environmental protection law and other acts. Journal of Laws of 2015, item 1434].

[11] Ustawa z dnia 27 kwietnia 2001 r. - Prawo ochrony środowiska, Dz.U. 2001 nr 62, poz. 627 z późn. zm. [Act of 27 April 2001 - Environmental protection law. Journal of Laws of 2001, no. 62, item 627].

[12] Ustawa z dnia 24 sierpnia 1991 r. o Państwowej Straży Pożarnej, Dz.U. 1991 nr 88, poz. 400 z późn. zm. [Act of 24 August 1991 on the State Fire Service. Journal of Laws of 1991, no. 88, item 400].

[13] Ustawa z dnia 20 lipca 1991 r. o Inspekcji Ochrony Środowiska. Dz.U. 1991 nr 77, poz. 335 z późn. zm. [Act of 20 July 1991 on the Inspection for Environmental Protection, Journal of Laws of 1991, no. 77, item 335].

[14] Ustawa z dnia 3 października 2008 r. o udostępnianiu informacji o środowisku i jego ochronie, udziale społeczeństwa w ochronie środowiska oraz o ocenach oddziaływania na środowisko. Dz.U. 2008 nr 199, poz. 1227 [Act of 3 October 2008 on making available information about environment its protection, the public's participation in environmental protection, as well as on environmental impact assessment. Journal of Laws of 2008, no. 199, item 1227]. 
[15] Ustawa z dnia 27 marca 2003 r. o planowaniu i zagospodarowaniu przestrzennym. Dz.U. 2003 nr 80, poz. 717 z późn. zm. [Act of 27 March 2003 on spatial planning and land-use management. Journal of Laws of 2003, no. 80, item 717].

[16] Rozporządzenie Ministra Środowiska z dnia 9 października 2002 r. w sprawie sposobu przedktadania wojewodzie informacji o rodzaju, ilości i miejscach występowania substancji stwarzajacych szczególne zagrożenie dla środowiska. Dz.U. 2002 $\mathrm{nr}$ 175, poz. 1439 [Ordinance of the Ministry of Environment of 9 October 2002 on the method of submitting to the voivode information on the type, quantity and location of substances posing a particular threat to the environment. Journal of Laws of 2002, no. 175, item 1439].

[17] Rozporzadzenie Ministra Środowiska z dnia 4 czerwca 2002 r. w sprawie szczegótowego zakresu informacji wymaganych do podania do publicznej wiadomości przez komendanta wojewódzkiego Państwowej Straży Pożarnej. Dz.U. 2002 nr 78, poz. 712 [Ordinance of the Ministry of Environment of 4 June 2002 on the detailed scope of information that is required to be made public by the Province Commander of the State Fire Service. Journal of Laws of 2002, no. 78, item 712].

[18] Rozporzadzenie Ministra Środowiska z dnia 30 grudnia 2002 r. w sprawie poważnych awarii objętych obowiazkiem zgłoszenia do Głównego Inspektora Ochrony Środowiska. Dz.U. 2003 nr 5, poz. 58 [Ordinance of the Ministry of Environment of 30 December 2002 on major accidents that are subject to notify the Chief Inspector of Environmental Protection. Journal of Laws of 2003, no. 5, item 58].

[19] Rozporzadzenie Ministra Środowiska z dnia 18 maja 2016 r. zmieniające rozporzadzenie w sprawie poważnych awarii objętych obowiazkiem zgłoszenia do Głównego Inspektora Ochrony Środowiska. Dz.U. 2016 poz. 799 [Ordinance of the Ministry of Environment of 18 May 2016 amending the regulation on major accidents covered by the obligation to notify the Chief Inspector of Environmental Protection. Journal of Laws of 2016, item 799].

[20] Rozporządzenie Ministra Spraw Wewnętrznych i Administracji z dnia 24 października 2005 r. w sprawie czynności kontrolno-rozpoznawczych przeprowadzanych przez Państwowa Straż Pożarna. Dz.U. 2005 nr 225, poz. 1934 [Ordinance of the Ministry of Interior Affairs and Administration of 24 October 2005 on the control-recognition actions carried out by the State Fire Service. Journal of Laws of 2005, no. 225, item 1934].

[21] Rozporzadzenie Ministra Rozwoju z dnia 29 stycznia 2016 r. w sprawie rodzajów i ilości znajdujacych się w zakładzie substancji niebezpiecznych, decydujących o zaliczeniu zakładu do zakładu o zwiększonym lub dużym ryzyku wystapienia poważnej awarii przemystowej. Dz.U. 2016 poz. 138 [Ordinance of the Ministry of Development of 29 January 2016 on the types and quantities of dangerous substances which presence at the plant decides the plant to be classified as the lower tier establishment or the upper tier establishment. Journal of Laws of 2016, item 138]. 
[22] Rozporzadzenie Ministra Rozwoju z dnia 23 lutego 2016 r. w sprawie raportu o bezpieczeństwie zakładu o dużym ryzyku. Dz.U. 2016 poz. 287 [Ordinance of the Ministry of Development of 23 February 2016 on the requirements to be met by the safety report for the upper tier establishment. Journal of Laws of 2016, item 287].

[23] Rozporzadzenie Ministra Spraw Wewnętrznych i Administracji z dnia 8 czerwca 2016 r. w sprawie wymagań, jakim powinny odpowiadać plany operacyjno-ratownicze. Dz.U. 2016, poz. 821 [Ordinance of the Ministry of Interior and Administration of 8 June 2016 on the requirements to be met by the emergency plans. Journal of Laws of 2016, item 821].

[24] Rozporzadzenie Ministra Infrastruktury z dnia 28 kwietnia 2004 r. w sprawie zakresu projektu studium uwarunkowań i kierunków zagospodarowania przestrzennego gminy. Dz.U. $2004 \mathrm{nr}$ 118, poz. 1233 [Ordinance of the Ministry of Infrastructure of 28 April 2004 on the scope of the draft of the study of conditions and directions for the spatial development of the municipality. Journal of Laws of 2004, no. 118, item 1233].

[25] Rozporzadzenie Ministra Infrastruktury z dnia 26 sierpnia 2003 r. w sprawie wymaganego zakresu projektu miejscowego planu zagospodarowania przestrzennego. Dz.U. 2003 nr 164, poz. 1587 [Ordinance of the Ministry of Infrastructure of 26 August 2003 on the scope of the draft of the local spatial development plan. Journal of Laws of 2003, no. 164, item 1587].

[26] Bieda A., Hanus P., Hycner R.: Geodezyjne aspekty planowania przestrzennego i wybranych opracowań projektowych. Wydawnictwo Gall, Katowice 2012.

[27] Kwartnik-Pruc A., Szafarczyk A.: Designating agricultural land for investment purposes and the requirements of environmental sustainability. Polish Journal of Environmental Studies, vol. 20, no. 4A, 2011, pp. 212-216.

[28] Front-Dąbrowska T.: The principles of changing land-use classification under special provisions in the areas of Poland where landslide movements and the risk of landslide movements occur. Geomatics and Environmental Engineering, vol. 9, no. 1, 2015, pp. 25-38.

[29] Rozporzadzenie Ministra Infrastruktury z dnia 26 sierpnia 2003 r. w sprawie sposobu ustalania wymagań dotyczacych nowej zabudowy i zagospodarowania terenu w przypadku braku miejscowego planu zagospodarowania przestrzennego. Dz.U. 2003 nr 164, poz. 1588 [Ordinance of the Ministry of Infrastructure of 26 August 2003 of on the method of determining the development conditions in the case when the spatial development plan is not prepared. Journal of Laws of 2003, no. 164, item 1588].

[30] Rozporzadzenie Ministra Infrastruktury z dnia 26 sierpnia 2003 r. w sprawie oznaczeń i nazewnictwa stosowanych w decyzji o ustaleniu lokalizacji inwestycji celu publicznego oraz w decyzji o warunkach zabudowy. Dz.U. 2003 nr 164, poz. 1589 [Ordinance of the Ministry of Infrastructure of 26 August 2003 on the designations and terminology used in the decision on development conditions and the decision on location of the public purpose investment. Journal of Laws of 2003, no. 164, item 1589]. 
[31] Rozporzadzenie Ministra Środowiska z dnia 9 września 2002 r. w sprawie opracowań ekofizjograficznych. Dz.U. 2002 nr 155, poz. 1298 [Ordinance of the Ministry of Environment of 9 September 2002 on the ecophysiographic documents. Journal of Laws of 2002, no. 155, item 1298].

[32] Ustawa z dnia 16 kwietnia 2004 r. o ochronie przyrody. Dz.U. 2018 poz. 1614 z późn. zm. [Act of 16 April 2004 on protection of nature. Journal of Laws of 2018, item 1614].

[33] Ustawa z dnia 20 lipca 2017 r. - Prawo wodne. Dz.U. 2017 poz. 1566 z późn. zm. [Act of 20 July 2001 on the Water law. Journal of Laws of 2017, item 1566].

[34] Ustawa z dnia 20 lipca 2017 r. o Krajowym Zasobie Nieruchomości. Dz.U. 2018 poz. 2363 z późn. zm. [Act of 20 July 2017 on the National Real Estate Stock. Journal of Laws of 2003, no. 80, item 717].

[35] Obwieszczenie Ministra Infrastruktury i Rozwoju z dnia 17 lipca 2015 r. w sprawie ogłoszenia jednolitego tekstu rozporzadzenia Ministra Infrastruktury w sprawie warunków technicznych, jakim powinny odpowiadać budynki i ich usytuowanie. Dz.U. 2015 poz. 1422 [Notice of the Minister of Infrastructure and Development of 17 July 2015 on the publication of a uniform text of the Ordinance of the Ministry of Infrastructure on the technical conditions to be met by buildings and their location. Journal of Laws of 2015, item 1422].

[36] Rozporzadzenie Ministra Infrastruktury i Budownictwa z dnia 14 listopada 2017 r. zmieniajace rozporządzenie w sprawie warunków technicznych, jakim powinny odpowiadać budynki i ich usytuowanie. Dz.U. 2017 poz. 2285 [Ordinance of the Ministry of Infrastructure and Construction of 14 November 2017 amending the ordinance on the technical conditions to be met by buildings and their location. Journal of Laws of 2017, item 2285].

[37] Kontić D., Kontić B.: Introduction of threat analysis into the land-use planning process. Journal of Hazardous Materials, vol. 163, 2009, pp. 683-700.

[38] Sebos I., Progiou A., Symeonidis P., Ziomas I.: Land-use planning in the vicinity of major accident hazard installations in Greece. Journal of Hazardous Materials, vol. 179, 2010, pp. 901-910.

[39] Hirst I.L.: Risk assessment a note on F-N curves expected numbers of fatalities, and weighted indicators of risk. Journal of Hazardous Materials, vol. 579, 1988, pp. 169-175.

[40] Francis A., Edwards A., Esipiner R., Haswell J., Bilo M., Carter D.: Weighted expectations: a new risk-based method for assessing land-use development proposal in the vicinity of major hazards. Journal of Loss Prevention in the Process Industries, vol. 12, 1999, pp. 379-390.

[41] Carter D.A, Hirst I.L.: 'Worst case' methodology for the initial assessment of societal risk from proposed major accident installations. Journal of Hazardous Materials, vol. 71, 2000, pp. 117-128. 
[42] Basta C., Neuvel J.M.M., Zlatanova S., Ale B.: Risk-maps informing land-use planning process. A survey on the Netherlands and the United Kingdom recent developments. Journal of Hazardous Materials, vol. 145, 2007, pp. 241-249.

[43] Bottelberghs P.H.: Risk analysis and safety policy developments in the Netherlands. Journal of Hazardous Materials, vol. 71, 2000, pp, 59-84.

[44] Delvosalle C., Fiévez C., Cornil N., Nourry J., Servranckx L., Tambour F.: Influence of new generic frequencies on the QRA calculations for land-use planning purposes in Walloon region (Belgium). Journal of Loss Prevention in the Process Industries, vol. 24, 2011, pp. 214-218.

[45] Delvosalle C., Robert B., Nourryb J., Yan G., Brohez S., Delcourt J.: Considering critical infrastructure in the land-use planning policy around Seveso plants. Safety Science, vol. 97, 2017, pp. 27-33.

[46] Khahzad N., Reniers G.: Risk-based design of process plants with regards to domino effects and land-use planning. Journal of Hazardous Materials, vol. 299, 2015, pp. 287-297.

[47] Salvi O., Gaston D.: Risk assessment and risk decision-making process related to hazardous installations in France. Journal of Risk Research, vol. 7, 2004, pp. 599-608.

[48] Cahen B.: Implementation of new legislative measures on industrial risks prevention and control in urban areas. Journal of Hazardous Materials, vol. 130, 2006, pp. 293-299.

[49] Taveau J.: Risk assessment and land-use planning regulations in France following the AZF disaster. Journal of Loss Prevention in the Process Industries, vol. 23, 2010, pp. 813-823.

[50] Demichela M., Pilone E., Camuncoli G.: Land-use planning around major risk installation: From EC directives to local regulations in Italy. Land-use Policy, vol. 38, 2014, pp. 657-665.

[51] Dechy N., Bourdeaux Y., Ayrault N., Kordek M.-A., Le Coze J.-Ch.: First lessons of the Toulouse ammonium nitrate disaster 21st September 2001, AZF plant in France. Journal of Hazardous Materials, vol. 111, 2004, pp. 131-138.

[52] Papazoglou I.A., Nivolianitou Z.S., Bonanos G.S.: Land-use planning policies stemming from the implementation of the SEVESO-II Directive in the EU. Journal of Hazardous Materials, vol. 61, 1998, pp. 345-353.

[53] Cozzani V., Bandini R., Basta C., Christou M.: Application of land-use planning criteria for the control of major-accident hazards: A case-study. Journal of Hazardous Materials, vol. 136, 2006, pp. 170-180.

[54] Basta C., Struckl M., Christou M.: Overview of roadmaps for land-use planning in selected Member States. EUR 23519 EN, JRC, Ispra 2008.

[55] Christou M., Gyenes Z., Struckl M.: Risk assessment in support to land-use planning in Europe: towards more consistent decisions? Journal of Loss Prevention in the Process Industries, vol. 24, 2011, pp. 219-226. 
[56] Pasman H., Reniers G.: Past, present and future of Quantitative Risk Assessment $(Q R A)$ and incentive it obtained from Land-Use Planning (LUP). Journal of Loss Prevention in the Process Industries, vol. 28, 2014, pp. 2-9.

[57] Hauptmans U.: A risk-based approach to land-use planning. Journal of Hazardous Materials, vol. A125, 2005, pp. 1-9.

[58] Vierendeels G., Reniers G.L.L., AleB.J.M.: Modelling the major accident prevention legislation change process within Europe. Safety Science, vol. 49, 2011, pp. 513-521.

[59] Markiewicz M.T.: A review of mathematical models for the atmospheric dispersion of heavy gases. PartI: A classification of models. Ecological Chemistry Engineering S, vol. 19, no. 3, 2012, pp. 297-314.

[60] Markiewicz M.T.: Matematyczne modelowanie rozprzestrzeniania się gazów cięższych od powietrza z uwzględnieniem przeszkód terenowych. Oficyna Wydawnicza Politechniki Warszawskiej, Warszawa 2018.

[61] Markiewicz M.T.: A review of models for the atmospheric dispersion of heavy gases. Part II. Model quality evaluation. Ecological Chemistry Engineering S, vol. 20, no. 3, 2013, pp. 763-782.

[62] Fabri L., Wood M.H.: Accident Damage Analysis Module (ADAM): Novel European Commission tool for consequence assessment - scientific evaluation and performance. Process Safety and Environmental Protection, vol. 129, 2019, pp. 249-253.

\section{Opinia badacza o projekcie przepisów prawnych dotyczących oceny zagrożenia poważną awarią $\mathrm{w}$ procesie planowania przestrzennego w Polsce}

Streszczenie: W artykule przedstawiono przegląd podstawowych regulacji dotyczących zagospodarowania przestrzennego terenów wokół niebezpiecznych zakładów przemysłowych i opinie autorki o projekcie nowego rozporządzenia Ministra Środowiska w sprawie określania odległości bezpiecznej od zakładów stwarzających zagrożenie wystąpienia poważnej awarii przemysłowej (zakładów typu Seveso). W Polsce brak jest obecnie przepisów prawnych dotyczących metody oceny zagrożenia poważną awarią wokół zakładów typu Seveso. Metoda typowych odległości bezpiecznych, rekomendowana w opracowaniu z 2007 roku zatytułowanym Metodologia wyznaczania bezpiecznych lokalizacji zakładów mogacych powodować poważne awarie, nie jest obowiązkowa do stosowania. Autorka podtrzymuje swoje zdanie wyrażone po raz pierwszy w 2015 roku, że polskie regulacje prawne dotyczące sposobu wyznaczania odległości bezpiecznej od zakładów stwarzających zagrożenie wystąpienia poważnej awarii $\mathrm{w}$ postaci ministerialnego rozporządzenia bezsprzecznie są potrzebne. Jeśli rozporządzenie zostanie wydane, przyczyni się do pełniejszego wdrożenia dyrektywy 2012/18/UE i ujednolicenia metody określania 
bezpiecznej odległości w całym kraju. Podejście, w którym wyznaczane są skutki potencjalnych poważnych awarii, wydaje się racjonalną opcją w polskich warunkach. Autorka sugeruje rozszerzenie projektu rozporządzenia Ministra Środowiska i określenie w nim referencyjnych narzędzi matematycznego modelowania skutków poważnych awarii. Warto jest również rozważyć wprowadzenie w postaci regulacji prawnych rozszerzonego opisu obszarów przeznaczonych pod lokalizację zakładów typu Seveso do wykorzystania w dokumentach planistycznych.

\section{Słowa}

kluczowe: zakłady typu Seveso, poważna awaria, zagospodarowanie przestrzenne, ocena zagrożenia, odległość bezpieczna 